Key words: neuropsychiatry, hematopoietic, stem cell, transplant, cancer, delirium, encephalopathy.

\title{
The Neuropsychiatry of Hematopoietic Stem Cell Transplantation
}

\author{
Mitchell R. Levy, MD \\ Jesse R. Fann, MD, MPH \\ Department of Psychiatry \& Behavioral \\ Sciences, University of Washington School \\ of Medicine, Seattle, WA (MRL, JRF) \\ Clinical Research Division, Fred Hutchinson \\ Cancer Research Center (JRF) \\ Psychiatry and Psychology Consultation \\ Service, Seattle Cancer Care Alliance \\ (MRL, JRF)
}

SEATTLE, WASHINGTON

USA

\begin{abstract}
Background and Objectives: Regimens incorporating hematopoietic stem cell transplantation (HSCT) have become widely utilized in disease treatments, particularly for cancer. These complex treatment programs also expose patients to central nervous system (CNS) toxicities from chemotherapy, irradiation, infection, metabolic effects and immunosuppression.

Methods: Relevant recent medical literature from Medline and bibliographies in pertinent publications are reviewed with a focus on those cases and studies pertaining to neuropsychiatric effects of HSCT.

Results: High rates of neuropsychiatric sequelae occur on a continuum from acute to chronic. Adverse outcomes include focal CNS deficits and severe global manifestations such as seizures, encephalopathy and delirium. More graduated effects on cognition, energy and mood are frequently seen, impacting patient function.

Conclusions: Additional research on neuropsychiatric outcomes and treatment interventions is needed in the HSCT setting. Risks for neuropsychiatric deficits should be part of an ongoing informed consent discussion among treating physicians, patients and families.
\end{abstract}

Received 4 December 2005

Accepted 10 January 2006

\section{Introduction}

Significant advances in therapy for multiple diseases of the blood cells and bone marrow have occurred over the last 3 decades. Many of the complex regimens developed to treat these entities involve the use of hematopoietic stem cell transplantation (HSCT). Approximately 50,000 trans- 
plants were performed worldwide in 2002, with expected increases of 10-15\% yearly (Goldman et al. 2002). Cells used in these regimens are harvested from self, related and unrelated donors and cord blood. Regimens utilizing these products involve typically marrow-diminishing applications of ionizing radiation and/or chemotherapy. Attempts are made to engraft the transplanted cells in an immunoreduced host -often with the hope for anti-tumor (graft-versustumor) effects from immunocompetent cells provided from the donor. Further efforts at immunomodulation are sometimes made to further reduce tumor burden or stimulate immune-system regeneration. In older or more medically frail patients, non-myeloablative regimens involving less toxic chemotherapy and radiation exposures have been more recently utilized (Geinstein et al. 2004).

Side effects, both acute and chronic, from these treatments are myriad. Acute effects include those related to immunosuppression, cytotoxicity and graft versus host disease. Chronically, graft versus host disease can develop, as well as sequalae affecting essentially every organ system. Different psychiatric syndromes may result from variations in the patient, type of illness treated, comorbid medical conditions, type of chemotherapy or radiotherapy and subsequent immunotherapy and resulting side effects (Appelbaum 2003).

\section{Methods}

We reviewed medical literature from MEDLINE (1980-2005) and bibliographies in pertinent publications for cases and studies regarding acute and long-term neuropsychiatric effects of HSCT in adults.
Many of these encompass neuropsychiatric syndromes outside the range of the American Psychiatric Association's Diagnostic and Statistic Manual (DSM) (Taylor et al. 2005). Our review included effects occurring on a continuum -from subtle emotional and cognitive problems to delirium and frank neurological deficits. Our search covered difficulties related to specific HSCT treatment agents and associated depression, anxiety, neuropsychological dysfunction and delirium.

\section{Results}

A range of conditioning therapies, often in combination, are used to destroy malignant cell and increase the potential for successful engraftment of donor cells. A number of neuropsychiatric effects have been noted with these regimens:

\section{Radiotherapy}

The effects of radiation are generally dependant upon dosage, duration, area targeted (whole body versus CNS) and any adjunctive chemotherapy. Much of the available literature cites outcomes for other cancer types. Armstrong et al. suggest the difficulty of estimating effects related to radiotherapy, chemotherapy or additive effects (Armstrong et al. 2004). Mechanisms for radiotherapy-related damage to CNS appear to be caused by factors beyond direct neuron apoptotic cell-death (Belka $e t$ al. 2001). Radiation may both elicit direct and indirect expression of cytokine mediators, including tumor necrosis factor (TNF)-alpha (Cammer 2000). These agents generate oligodendrocyte apoptosis and 
reduction of progenitor stem cell populations (van der Maazen et al. 1991, van der Maazen et al. 1990). Belka et al. speculate that later neurotoxicity represents a failure of myelin recovery, (Belka et al. 2001) with additive contributions from radiotoxicity to vascular (Eissner et al. 1995) and subventricular cells (Tada et al. 1999).

Many regimens for HSCT employ total body irradiation (TBI) as preparative treatment. TBI may precipitate both acute and longer-term neuropsychiatric effects. Within 2 days to one week, short-term effects including drowsiness, heachache and emesis can appear. Subacutely, in 6 or more weeks, reversible fatigue and somnolence are complaints. Cases of transient somnolence and EEG background slowing have been noted subsequent to radiotherapy (Goldberg et al. 1992).

Longer-term deficits in reaction time, attention, concentration and difficulty with reasoning and problem-solving have been characterized as related to dosage of TBI administered (Andrykowski et al. 1990). Other prospective studies have suggested little change in cognitive function for cohorts followed longer-term (Wenz et al. 2000). Armstrong et al. point to the paucity of data covering outcomes for adult patients after several years. Older patients may be at higher risk for cognitive declines related to pre-existing vascular disease and medical comorbidity (Armstrong et al. 2004). Whitematter lesions present at high rates (75$86 \%$ ) in these patients (Wassenberg et al. 2001). Very high radiation dosing to focal CNS areas has been linked to necrotic effects resulting in focal neurological signs, seizures or increased intracranial pressure (Belka et al. 2001). Lastly, TBI may potentiate neurotoxicity from other immunosuppressive agents (Bartynski et al. 2004).

\section{Chemotherapy}

Different chemotherapeutic agents are often combined with other drugs and with radiotherapy to provide immunosuppression or ablation. Toxic effects of individual agents are therefore sometimes difficult to discern. Higher dosages often used with HSCT put patients at risk for neurotoxicity (Verstappen et al. 2003) or for adverse effects from other immunosuppressive agents (e.g. cyclosporine) (Bartynski et al. 2004). Most, if not all, have been implicated in at minimum subtle reversible cognitive disorder after transplantation (Syrjala et al. 2004a). Neuropsychiatric syndromes, primarily described in case studies, related to specific agents include:

Busulfan has been associated with seizures, particularly at higher dosages. Cases of abnormal EEG changes have been noted in patients undergoing HSCT ( $\mathrm{La}$ Morgia et al. 2004).

Carmustine (BCNU) and the related alkylating agent lomustine (CCNU) generate toxicity generally at higher dosages as typical with HSCT. Cases of myeloencephalopathy and seizures evidencing over time after treatment have been noted in intra-arterial treatment for glioma, for which HSCT has been attempted (Mahaley et al. 1986).

Cisplatin, a platinum-containing antineoplastic, is commonly used for treatment of germ-cell tumors, from which much of the available literature has been derived. This agent has been linked to high incidence of peripheral neuropathy, averaging $57 \%$ in one survey (Tuxen et al. 1994). In an extensive literature, review, Troy et al. concluded that such involvement is primarily for large myelinated sensory fibers generating deficits for vibration, touch and occasional- 
ly proprioception (Troy et al. 2000). Shocklike sensations descending along the legs and feet upon neck flexion (Lhermitte's sign) have been encountered with this agent (Inbar et al. 1992). Cisplatin-associated ototoxicity at higher dosages occurs frequently, related to conduction delay in between the organ of Corti and the midbrain (Hansen et al. 1989). Patients may suffer ophthalmologic deficits, including blindness, (Cersosimo 1989) as well as autonomic neuropathy (Hansen 1990).

In addition to often dosage-related peripheral and cranial neuropathy syndromes (Siegal et al. 1990), cisplatin has been associated with rare encephalopathic conditions. Posterior leukoencephalopathy syndromes similar to those often related to immunosuppressive exposure have been noted. Symptoms have included seizures and central deficits such as cortical blindness. Reversible white-matter changes have been detected in occipital, parietal and frontal lobes (Ito et al. 1998, Lyass et al. 1998). Syndrome of inappropriate antidiuretic hormone (SIADH) with associated encephalopathy has also been noted in connection with this agent (Otsuka et al. 1996).

Troy et al. suggest the possibility for more subtle effects on higher-order functions such as visuospatial, reaction time, memory, verbal ability and executive processes. They draw analogy to other heavy-metal toxic syndromes and suggest risks to more sensitive areas of the hippocampus, amygdala, striatum and basal ganglia and frontal regions. Lastly, strokesyndromes (in other cancer treatment regimens), appearing both ischemic and thrombotic in character, have been noted (Doll et al. 1986; Troy et al. 2000).

Cyclophosphamide and its analog, ifosfamide, both demonstrate neurotoxicity risks. Ifosfamide has been frequently connected to cases of encephalopathy with fairly rapid resolution. Prior history of cerebral events with ifosfamide, renal insufficiency or cotreatment with cisplatin, have been associated with risk for such mental status changes. Treatment with methylene blue and hydration may facilitate resolution (Di Maggio et al. 1994, Rieger et al. 2004). More rarely ifosfamide has generated syndromes involving seizures and focal events such as ataxia, cranial and peripheral neuropathy and extrapyramidal dysfunction (Klastersky 2003). Cyclophosphamide has been less commonly implicated in such effects in adults with cases of visual change and confusion at higher dosages observed (Kende et al. 1979).

Cytarabine-related cerebellar effects occur at higher dosages of this pyrimidine analogue and necessitate stopping this agent. Symptoms of somnolence and sometimes encephalopathy tend to precede an ataxia of variable severity. Damage to cerebellar Purkinje cells is implicated (Friedman et al. 2001). While the syndrome may resolve in some patients, age over 40, decreased liver and renal function or neurological dysfunction, may be risks for cerebellar injury. Signal-enhancement on magnetic resonance imaging (MRI) may precede clinical changes (Zawacki et al. 2000). Cytarabine has also been associated with cranial and peripheral neuropathy and brachial plexopathy, as well as a GuillianBarré-like presentation (Osborne et al. 2004).

Etoposide has rarely been associated with peripheral neuropathy in HSCT (Imrie et al. 1994). Treatment for other cancers has been associated with effects such as confusion, seizures and focal effects including optic neuritis and cortical blindness, for which 
HSCT patients may be at risk (Leff et al. 1988).

Fludarabine, a purine analog, has been occasionally associated at lower dosages with headache, somnolence, confusion and paresthesia, with delayed progressive encephalopathy common at higher dosages (Cheson et al. 1994, Warrell et al. 1986, Chun et al. 1986). Cases have been reported of progressive multifocal leukoencephalopathy (PML) (Gonzalez et al. 1999, Vidarsson et al. 2002). PML is characterized as a subacute demylenating disease of the central nervous system (CNS) caused by reactivation of latent polyoma viruses (Padgett et al. 1983). Symptoms typically include progressive dementia, motor dysfunction, visual loss and often death (Wang 2004). Viral particles enter the CNS via oligodendrocytes and then enter glial cells via receptor-mediated clathrin-dependent endocytosis (Pho et al. 2000). MRI appearance in $\mathrm{T}_{2}$-weighted images is generally seen as asymmetric nonenhancing bilateral bright lesions in the white and sometimes grey matter and brain stem, which may become confluent (Edelman et al. 1993).

Methotrexate's neurotoxic effects include aseptic meningitis and, particularly at higher dosages, encephalopathy involving progressive depression of consciousness and the development of seizures. These syndromes may present acutely or progress to more chronic, dementia-like conditions (Rubnitz et al. 1998, Walker et al. 1986). Most seriously, a leukoencephalopathy characterized by delayed deficits ranging from subtle learning difficulty to dementia with somnolence, gait disturbance, aphasia, hemiparesis and even death has been observed (Rubinstein et al. 1975). One series noted $26 \%$ of adult longer-term survivors of primary cerebral lymphoma with this devastating complication at 68 months
(Blay et al. 1998). Neuroimaging changes, including cerebral atrophy, diffuse white matter hyperintensities, ventricular enlargement and occasionally calcifications visible on MR imaging, may precede clinical effects (Lien et al. 1991).

Intrathecal methotrexate is associated acutely with high rates of arachnoiditis in 5$40 \%$ of patients. Symptoms include headache, nausea, vomiting, and meningeal signs with raised intracranial pressure. These may resolve over several days. Subacutely, intrathecal methotrexate can generate changes in mental status, progressive paraparesis and delirium (Brown et al. 1998). Chronic intrathecal methotrexate may generate a leukoencephalopathy similar to that caused by high-dose methotrexate (Moore et al. 2002). Methotrexate's neurotoxic effects may be the result of direct injury or of interference with folate metabolic pathways and the buildup of excitatory amino acid products (Vezmar et al. 2003).

Thiotepa has been implicated in neuropsychiatric effects such as progressive leukoencephalopathy, (Brown \& Stoudemire 1998, Lai et al. 2004) particularly at higher dosages in combination with above agents. It has also been shown to elicit neurotoxic effects in animal studies (Rzeski et al. 2004).

Vincristine manifests dose-limiting peripheral neurotoxicity, related to interference with axonal microtubules and intracellular transport (Brown \& Stoudemire 1998). More rarely, reports of intrathecal administration leading to fatal encephalopathy with myelopathy as well as delirium, seizures and cortical blindness have been noted (Tuxen \& Hansen 1994). Encephalopathy has been seen in conjunction with SIADH induced by vincristine (Hammond et al. 2002, Hussain et al. 1993). 


\section{Immunomodulatory Therapy}

In order to sustain a chemotherapeutic response or host anti-tumor immune effect or prevent graft-versus-host disease (GVHD), various agents have been employed. Agents with known neuropsychiatric effects and related syndromes include the following:

Corticosteroids act via the modulation and downregulation of lymphocytes and lymphocyte actions (Scudeletti et al. 1996). They have been well known since 1950 (Rome et al. 1950) as risks for a range of neuropsychiatric conditions. Corticosteroids have a role in both pretreatment chemotherapy for HSCT and suppression of GVHD. Neuropsychiatric syndromes related to steroid therapy represent a heterogeneous entity. Symptoms including mood changes or lability, frank mania, psychosis, depression, cognitive changes and delirium/confusion have been reported. Onset typically occurs within days to weeks and reverses with steroid taper (Lewis et al. 1983). EEG changes have been seen without characteristic pattern (Bleistein et al. 1989). Incidence rates, primarily drawn from treatment studies for other conditions, have been variable: 3-57\% (Lewis et al. 1954, Lewis \& Smith 1983, Sergent et al. 1975).

Most reviews have emphasized a predominance of mood-related changes; including both mania and depression. It is generally clinically inferred that mania predominates, although this has not been unanimous in the literature (Sirois 2003). Reports have also cited reversible dementia (Varney et al. 1984) and delirium (Stoudemire et al. 1996). The large Boston Collaborative Study established a threshold for neuropsychiatric effects as increasing markedly at doses above $80 \mathrm{mg} /$ day of prednisone (Acute adverse reactions to prednisone in relation to dosage 1972). Neuropsychiatric symptoms may also be precipitated by rapid steroid dosage changes and may not always correlate with absolute dosage. More subtle cognitive changes may occur, with studies showing short-term reversible decrement in auditory-verbal learning (Naber et al. 1996, Wolkowitz et al. 1990), and longer-term impairments in declarative memory function (Keenan et al. 1996, Newcomer et al. 1994). While there is currently little data on steroid-associated effects specifically in HSCT, corticosteroids have been shown to contribute to neurotoxicity syndromes with other immunomodulatory agents. Additionally, they may well contribute to longerterm functional difficulties experienced by cancer HSCT patients.

Cyclosporine (CSP), a calcineurin-mediated immunosuppressant, has well-documented association with neurotoxicity in other transplantation settings both acutely (Craven 1991) and long-term (Strouse et al. 1998). CSP has been found to lead to neurotoxicity at any point during HSCT, regardless of CSP blood levels; this effect is more likely in patients receiving more complex chemotherapy regimens (Bartynski et al. 2004, Edwards et al. 1996). In a series of 129 patients undergoing allogeneic HSCT, Trullemans et al. noted an incidence rate of $4.6 \%$ for neuropsychiatric effects -often with prodromal hypertension and headache occurring acutely/subacutely (3-37 days). Steroid and other preparative drug exposures were viewed as risk factors. They further noted in their study group seizures, symptoms of hemiparesis, and cortical blindness. Findings on MRI included cortical/subcortical white-matter hyperintensities -these suggest a local vascular etiology (Trullemans et al. 2001). Others have implicated microangiopathic phenomena in cyclosporine-related neurotoxicity (Bartynski et al. 1997, Pettitt et al. 1994). Risks for 
cyclosporine-mediated toxicity include: HLA disparity, (Zimmer et al. 1998) hypocholesterolemia, hypomagnesemia, hypertension, acute renal failure, corticosteroid therapy, pre-treatment with etoposide, TBI, (Bartynski et al. 2004) acute GVHD and post-transplant microangiopathic hemolytic anemia (Pettitt \& Clark 1994).

FK506 (Tacrolimus) also functions by means of calcineurin inhibition. Neuropsychiatric side effects have been well-documented in other populations, (Neuhaus et al. 1994) linked to impairment of the bloodbrain barrier (Kaczmarek et al. 2003). Cases have also been noted in HSCT patients (Misawa et al. 2000). Posterior reversible encephalopathy syndrome (PRES) has been associated with both FK506 and CSP. This syndrome generally involves reversible imaging changes involving predominantly parietal and occipital lobe brain areas (Ay et al. 1998, Covarrubias et al. 2002, Hinchey et al. 1996, Mukherjee et al. 2001, Provenzale et al. 2001). Diffusion-weighted images on MRI have demonstrated vasogenic edema in areas of signal change and more rarely frank infarction (Covarrubias et al. 2002). Cases involving pretreatment with TBI may predispose for lesions into white matter versus those in cortical locations (Bartynski et al. 2001).

FK506 toxicity is likely associated with similar risks as in CSP toxicity (Zimmer et al. 1998, Cooper et al. 1989, Boogaerts et al. 1982, Bartynski et al. 2004). Lesions are heavily represented in critical cerebrovascular watershed areas. Investigators have therefore attributed aspects of PRES to hypertension (common during HSCT), (Mark 1990, Scherrer et al. 1990) vasospasm (Bartynski et al. 1997, Zimmer et al. 1998) and thrombotic microangiopathy (Holler et al. 1989). In a case review, Bartynski et al. suggest the role of a general endothelial injury process, similar to eclampsia, generating vasospasm and resulting hypoxia. In their survey, for both CSP and FK506, onset occurred after days with most patients presenting with symptoms within the first month after HSCT, then additional peaks at 2-3 months and then later (5-13 months) (Bartynski et al. 2004).

Longer-term studies in aggregate have suggested that discontinuation of the implicated calcineurin inhibitor leads to resolution of neurological symptoms in the majority of cases $(70 \%$ in one series after several months). Neurotoxicity after exposure to these agents often heralds the onset of GVHD and generally poor prognosis (Chohan et al. 2003). Although switching from CSP to FK506 has been attempted, it is not clear that this decreases the likelihood of neuropsychiatric problems (Neuhaus et al. 1994).

Granulocye macrophage stimulating factor (G-MSF) is utilized for treatment of neutropenia related to chemotherapy. GMSF has also been associated with PRES, displaying MRI changes in the occipital and parietal regions (Leniger et al. 2000).

Interleukin-2 (IL-2) has been connected with neuropsychiatric effects in children (Classen et al. 2001) and in animal studies, possibly mediated by immune-cell infiltration (Hanisch et al. 1996). IL-2 effects have been noted on a continuum, from subtle alterations in energy and cognition to depression or mania (Strite et al. 1997, Walker et al. 1997). In treatment for other cancers, IL-2 has been associated with mental status changes, seizures and focal lesions (Karp et al. 1996). High case-rates have been reported for behavioral changes, including delirium, in $10-50 \%$ of patients receiving IL-2 infusions (Lerner et al. 1999). 
Interferon-alpha, a naturally occurring inflammatory mediator, has been extensively used to treat other medical conditions, particularly hepatitis C. Recent protocols have utilized interferon-alpha in HSCT treatment (Aviles et al. 2005). The extensive database detailing neuropsychiatric risks from interferon-alpha is derived largely from its use for hepatitis $\mathrm{C}$ and to a lesser extent for malignancies such as malignant melanoma and renal cell carcinoma (Raison et al. 2005). These effects, likely related to interferon-alpha release during chemotherapies, may be of concern for use in HSCT.

During treatment for other malignancies, interferon-alpha has been implicated in acute confusional states (delirium), disorientation, lethargy, somnolence, psychomotor retardation, aphasia and agraphia, and psychosis (Adams et al. 1988, Farkkila et al. 1984, Iivanainen et al. 1985, Mattson et al. 1983, Meyers et al. 1991, Niiranen et al. 1988, Poutiainen et al. 1994, Rohatiner et al. 1983, Smedley et al. 1983). These changes have occasionally been noted as persisting beyond discontinuation (Meyers et al. 1991). It has been theorized that rapid onset toxic effects may correlate with interferon-alpha's stimulation of opioid receptors or alterations in dopamine turnover (Schaefer et al. 2003).

Mood symptoms have been most notoriously connected with the employment of interferon-alpha. Depressogenic effects of interferon-alpha have been attributed to alterations in central serotonin neurotransmission. These changes may be occurring directly, related to changes in $5-\mathrm{HT}_{2}$ receptor function or via alterations in the metabolism of the serotonin precursor tryptophan (Menkes \& MacDonald 2000, Taylor \& Feng 1991, Yang et al. 2004).
Alternatively, the group led by Capuron has delineated a split in onset between more purely neurovegetative and somatic symptoms versus those of mood, anxiety and cognition. In a study observing treatment for malignant melanoma, features of altered sleep, pain, anorexia and fatigue occurred after 2 weeks with features of depression developing later (Capuron et al. 2002). Capuron suggests in further work the possible role of induction of depression via interferon-alpha's induction of corticotropinreleasing factor (CRF). CRF is implicated in some forms of endogenous depression, and Capuron links this association (Owens et al. 1993) to the responsiveness of interferonalpha-induced depression to antidepressant therapies (Musselman et al. 2001). By contrast, more purely neurovegetative interferon-alpha-induced symptoms appear more resistant to antidepressants (Capuron 2004). These somatic symptoms are suggested to occur separately as part of the general proinflammatory response common in medical illness: a so-called "sickness-syndrome" (Dantzer 2005). Much less commonly, symptoms of mania have occurred as part of interferon-alpha therapy or withdrawal (Carpiniello et al. 1998, Monji et al. 1998).

Rituximab directs an antibody against the CD20+ receptor facilitating immunusuppression. Rituximab-associated cases of infection with JC papovavirus or cytomegalovirus (CMV) have been recorded in autologous and allogeneic (Steurer et al. 2003) HSCT patients. Matteuchi et al. report a diagnosis of PML in a patient with non-Hodgkins's lymphoma (NHL) heavily pretreated with sequential rounds of chemotherapy. This case involved the onset of mental status changes and ataxia several months post-transplant (Matteucci et al. 2002). 
Goldberg and co-investigators also cite two cases of PML after HSCT and Rituximab with a similar clinical course, and they review the better-known occurrence of PML in other states of immunosuppression (i.e. HIV) and delayed T-cell reconstitution (Goldberg et al. 2002). Both cidofir and IL2 have been tried in treatment of PML (Osorio et al. 2002, Shitrit et al. 2005). Perhaps by increasing CD4+ count, IL-2 has shown some benefit (Buckanovich et al. 2002).

\section{Global Clinical Syndromes}

\section{Neuropsychological and Functional Changes:}

Subjective complaints of cognitive difficulty -sometimes referred to as "chemobrain"- are common acutely and longer-term for cancer patients. Difficulties quantifying these deficits arise due to challenges assessing baseline cognition, effects related to the cancer itself and influences of comorbid medical conditions. Not uncommonly, HSCT populations have demonstrated cognitive deficits, prior to transplantation, compared to medically-ill controls, likely related to severe underlying medical illness and prior treatment (Andrykowski et al. 1992, Harder et al. 2005). Results may vary based upon time of sampling (acute versus chronic) or the instrument used to assess cognitive function.

An extensive recent review by AndersonHanley et al. highlighted some of these methodological challenges. They attempted to look at neuropsychological difficulties studied for cancer patients in aggregate. They note the challenge of making comparison between patients and controls versus pretreatment and post-treatment. Over the domains of executive, verbal, motor and memory functioning, they note statistically significant impairments compared with con- trol subjects and normative data. They suggest these effect sizes as medium to large for executive and verbal memory and small to large for motor function. Anderson-Hanley et al. acknowledge that these results exclude patients receiving direct brain irradiation or more intensive and higher-dosage regimens (Anderson-Hanley et al. 2003).

It would be expected that more intensive HSCT conditioning regimens would be more likely to create cognitive and functional deficits. This appears to have been confirmed by other studies of neuropsychiatric risks from radiation or intrathecal chemotherapy in the generation of subsequent deficits. These cognitive effects particularly target higher-order processes (e.g. executive function) and are likely additive (Andrykowski et al. 1989). It is concerning that measures of cognitive ability (Trailmaking Test Part B, Controlled Oral Word Association Test) demonstrate declines in executive processing over the acute course of HSCT. In a study by Ahles, these declines were in contrast to general improvement in levels of anxiety and depression (Ahles et al. 1996). Carefully assessing cognitive performance over the course of transplant and at intervals of 80 days and one year posttransplant, Syrjala et al. noted deficits globally in cognitive function. These spanned the domains of attention, information processing speed, learning, visual-motor integration, verbal fluency and verbal memory. Patients experienced nearly uniform returns close to pre-treatment performance baselines after one year (Syrjala et al. 2004a).

As a proxy for global physical, cognitive and emotional function, the majority of studies have reported high rates of return to work, ranging from $60 \%-84 \%$, several years after transplantation (Syrjala et al. 1993, Bush et al. 2000, Hensel et al. 2002, Syrjala et al. 2004b). There is however, 
some implication of a "ceiling effect" in functional attainment and quality of life (Andrykowski et al. 1989). Despite high levels of return to work or school, significant numbers of patients report high levels of cognitive fatigue even three years after HSCT (Hjermstad et al. 2004).

\section{Depression and Anxiety:}

Rates of reported depression are likely influenced to some degree by the screening instrument employed and specificity of diagnosis (e.g. using rating scale cutoff points versus clinical diagnosis). Pre-transplant factors related to illness severity, social support, coping style and pre-existing depression may also weigh heavily on depression incidence (Grassi et al. 1996, Massie et al. 1998). Patients may present pre-transplant with elevated rates of depressive symptoms. During HSCT distress may further increase: $18 \%$ depressive symptom rates noted in one survey (Vose et al. 1992). These symptoms include changes in acute distress that may not meet formal criteria disorder for a DSM-IV diagnosis of a major depressive or anxiety disorder.

In a study focused specifically on patients hospitalized for HSCT, Prieto et al. reported significantly elevated rates of initial anxiety, which resolved as patients' anticipated fears for treatment were addressed. This was in contrast to depressive symptoms which rose at 7 days into HSCT and closely paralleled physical distress. Mood improved, as did physical health status, as treatment progressed (Prieto et al. 2005b). Post-traumatic stress symptoms assessed in a cohort by Wettergren et al. were elevated in a cohort followed through HSCT, with improvement over time (Wettergren et al. 1999). Similar findings were observed for lymphoma patients with elevated rates of depression, correlated with fatigue, occurring at day 7 (El-Banna et al. 2004).

A group led by Hjermstad outlined a trajectory for mood complaints 2-4 weeks pretransplantation, with consistent return to baseline levels after 4 months. They concluded that somatic complaints were a driver for depression (Hjermstad et al. 1999). Later work has charted high rates of cumulative psychiatric symptoms, including combined adjustment, mood and anxiety disorders (42.3\% using DSM-IV criteria), with associated increased hospital length of stay for HSCT (Prieto et al. 2002). Although rates of anxiety and depression decline over time in most surveys, they are likely related to physical symptoms. Depression and distress adversely impact functioning after transplantation (Lee et al. 2005, Meyers et al. 1994).

Fatigue related to cancer is a subjective and multidimensional phenomenon impacting physical and cognitive functioning and likely overlaps with depression. Rates of fatigue during cancer treatment generally range from $25 \%$ to $99 \%$ and are higher than controls during HSCT (Blesch et al. 1991, Hann et al. 1999, Monga et al. 1999). Patients relate impacts on daily and employment function related to high levels of unaddressed fatigue (Curt et al. 2000, Vogelzang et al. 1997). Etiology may relate to effects of elevated levels of cytokines on the CNS hypothalamic-pituitary axis or possibly a Tcell mediated inflammatory process (Bower et al. 2005, Bower et al. 2002, Bower et al. 2003).

Studies have attempted to follow individuals longer term after HSCT for symptoms of psychological distress. Researchers have attributed greater levels of depressive symptoms in the period from hospital discharge to 100 days after HSCT to correlate with 
adjustment into more normal life. Depression and other markers for distress may be subject to influences from other life stressors and changes in support (McQuellon 1998). In a cohort of patients treated with HSCT for CML, Chang et al. saw overall levels of depressive symptoms and alcohol usage decline over time. Declines in Beck Depression Inventory scores were statistically significant. They note higher quality of life related to younger age and more prestigious employment status (Chang et al. 2005).

Symptoms of depression during transplantation were not found by Chang's group to affect 1-year survival, although they were associated with higher death-rates in the subsequent 1-2.5 year period (Chang et al. 2004; Chang et al. 2005). Others have found elevated risks for mortality associated with depression in the 6-12 month period after HSCT, after controlling for transplant type and medical risks, (Loberiza et al. 2002) and recently have shown greater risk for dying in those patients with major depression at 1 and 3 year follow-up (Prieto et al. 2005a).

Rates of anxiety may remain elevated in HSCT patients after one year compared to the general population (Hjermstad et al. 1999). Syrjala et al. suggest delay in emotional recovery compared to physical improvement. They note $22 \%$ of patients meeting criteria for clinical depression within a five-year period after HSCT. Similar to the general population and other studies in HSCT, they related higher risk for women after treatment (Heinonen et al. 2001, Syrjala et al. 2004b). A review by Neitzert et al. across multiple studies, populations and time-points was consistent for elevated levels of depression and psychosocial distress. HSCT patients appeared on a range of time-scales to be doing more poor- ly than either normal controls or patients undergoing other cancer treatments. They note the difficulty of drawing conclusions from varied sources and methods (Neitzert et al. 1998). Studies at 3 years out have not uniformly noted high levels of post-transplant depressive or anxiety symptoms, however (Hjermstad et al. 2004). Finally, difficulties with emotional adjustment after HSCT also correlate with significant posttransplantation fatigue (Knobel et al. 2000).

While a recent review (Spiegel et al. 2003) suggests the relationship of depression to cancer incidence remains ambiguous, it is clear that mood symptoms adversely affect patient outcomes. Cancer progression may be related to poor adherence and self care (Pirl et al. 1999). Direct effects mediated through hormonal and immune axes related to depression may theoretically promote cancer progression. Studies have suggested levels of chronic HPA axis activation often characteristic of depression (Yehuda et al. 1996) reducing Tcell mediated immune responses (Moynihan 2003) and affecting natural killer cell immune surveillance (Davis et al. 2001). This is more consistently seen in states of chronic versus acute stress (Levy et al. 1987). Animal models have shown rapid cancer growth in animals with surgically blunted cortisol rhythm (Filipski et al. 2002). Elevated levels of glucocorticoid hormones seen in depression may suppress existing immune response (Callewaert et al. 1991) or accelerate tumor metabolism. (Rowse et al. 1992).

Data in depressed humans show a general trend towards suppression of immune and particularly natural killer cell function. Depression-mediated suppression of MHC1 receptors on tumor cell surfaces may permit these to escape destruction by the immune system (Reiche et al. 2004). These 
findings may help explain alterations in outcome related to depression or distress in HSCT (Levav et al. 2000). Lastly, alterations of cellular DNA repair and dysregulation of cell apoptosis associated with distress may facilitate cancer progression (Kiecolt-Glaser et al. 1985, Tomei et al. 1990). Ultimately, a "bidirectional model" may prevail: aspects of cancer stress and treatment (such as interferon-alpha) and immune changes influencing depression incidence, and depression likewise altering immune function (Reiche et al. 2004).

\section{Delirium:}

The syndrome of delirium presents as one of the most significant neuropsychiatric concerns in HSCT. Delirium is defined as a constellation of acute changes involving level of consciousness, attention, cognition and perception often with symptom fluctuation, linked to concomitant medical conditions, medications or other substances (American Psychiatric Association, 2000). Associated EEG changes typically show loss of alpha rhythm and its replacement by theta and delta waves over posterior areas, with possible dysfunction of attentional networks associated with the anterior cingulate cortex (Jacobson et al. 2000, Reischies et al. 2005).

Given risks from chemotherapy, immunusuppression, infections, medications and associated metabolic and medical comorbidities, it is not surprising that high rates of delirium have been noted in HSCT - up to $50 \%$ in one study (Fann et al. 2002). A recent study cited incidence as $18 \%$ during hospitalization in non-terminally ill patients, which increased length of stay (Ljubisavljevic et al. 2003). Etiology is typically multifactorial (Fann et al. 2003). Agents commonly used in cancer treatment with strong linkage to delirium include opi- oid analgesics, sedatives, corticosteroids and anticholinergic medications (Han et al. 2001).

In hospitalized cohorts with malignancies, delirium has been associated with increased mortality ratios of 6.2 during hospitalization and 14.1 1-5 years afterwards (van Hemert et al. 1994). Delirium in advanced stage cancers and terminal illness has been strongly associated with shortened time of survival (Caraceni et al. 2000, Metitieri et al. 2000, Morita et al. 1999). On a consultation-liaison service, Olofsson found higher incidence, shorter duration and better prognosis in those patients presenting with the hyperalert delirium variant. It was also found that treatment of delirium was associated with better outcome (Olofsson et al. 1996).

Studies more closely examining delirium in HSCT populations have suggested high rates of distress (Breitbart et al. 2002) and incidence typically within 4 weeks posttransplantation (Fann et al, 2002, Prieto et al. $2005 b$ ). Delirium risks in severely immunocompromised HSCT patients include encephalitis related to reactivation of latent human herpes virus 6 (HHV-6), varicellazoster and CMV (Hackanson et al. 2005, Hentrich et al. 2005, Julin et al. 2002). HHV6 encephalitis may also present with behavioral changes and nonspecific MRI findings (Muta et al. 2005, Tsujimura et al. 1998, Zerr et al. 2005). Fann et al. recorded delirium in HSCT marked by disturbance of sleep-wake cycle, psychomotor abnormality and degraded cognitive function. Incidence rates for delirium episodes were $50 \%$ with average duration of 10 days. Symptoms of frank psychosis were rare, and delirious patients evidenced higher rates of fatigue, pain and affective distress than non-delirious patients. The predominant psychomotor presentation was of a more hypoactive delirium in $86 \%$ of 
such patients. Fann's group found three primary delirium symptom domains in psychosis/behavior, cognition and mood/level of consciousness. They noted prodromal symp- toms involving attention, disturbed perceptions, and changes in cognition peaking at approximately 2 weeks post-transplantation preceding frank delirium (Fann et al. 2005).

Table I

Summary of Neuropsychiatric Effects from Specific Agents Utilized in HCST.

\begin{tabular}{lll} 
Agent & Acute/Sub-acute Effects & Long-term Effects \\
\hline Radiotherapy & Emesis, drowsiness, headache, & Cognitive deficits, \\
& fatigue, somnolence. & focal signs, seizures, increased \\
& ICP (high dosage).
\end{tabular}

\section{Chemotherapy}

Busulfan

Carmustine (BCNU)/

lomustine (CCNU)

Cisplatin

Cyclophosphamide

Cytarabine

Etoposide

Fludarabine

Ifosfamide

Methotrexate

Thiotepa

Vincristine

Immunomodulatory Therapy

Corticosteroids

Cyclosporine

FK506

G-MSF

Interleukin-2

Interferon-alpha

Rituximab
Seizures.

Seizures, myeloencephalopathy

Peripheral/cranial/autonomic neuropathy,

ototoxicity, leukoencephalopathy, seizures,

SIADH, stroke-like episodes.

Visual changes, confusion.

Somnolence, ataxia, peripheral/cranial neuropathy, Guillian- Barré Syndrome.

Peripheral neuropathy, confusion, seizures, optic neuritis, cortical blindness.

Headache, somnolence, confusion, paresthesia, PML.

Encephalopathy, seizures, focal deficits

Arachnoiditis, aseptic meningitis, leukoenphalopathy, seizures, paraparesis, delirium (especially intrathecal).

Dementia-like changes.

Leukoencephalopathy

(especially intrathecal).

Cognitive deficits

Leukoencephalopathy.

Peripheral neuropathy, encephalopathy, SIADH.

Mood lability, mania, depression, psychosis, delirium, cognitive deficits.

Headache, seizures, focal deficits, cortical blindness, PRES.

PRES.

PRES.

Behavioral changes, delirium, fatigue, depression, mania, cognitive deficits, seizures, focal changes.

Delirium, somnolence, depression, aphasia, Cognitive deficits. agraphia, psychosis PML.

$\mathrm{ICP}=$ Intracranial pressure, $\mathrm{PML}=$ progressive multifocal leukoencephalopathy, $\mathrm{PRES}=$ posterior reversible encephalopathy syndrome, SIADH = Syndrome of inappropriate anti-diuretic hormone. 


\section{Discussion}

Patients undergoing HSCT are subject to a range of neurotoxicities of varying severity and duration. Future studies should aim towards standardizing symptom rating instruments and controlling for pertinent treatment-related variables (e.g. allogeneic/autologous transplant status, prior chemotherapy exposure, age and comorbid medical illnesses) (Neitzert et al. 1998). More recently, research has moved in the direction of close longitudinal screening and quantification of risk factors for sensitivity to specific agents or clinical syndromes (Neitzert et al. 1998, Fann et al. 2002, Syrjala et al. 2004b). For example, it would be helpful to know which patients are susceptible to CSP-mediated leukoencephalopathy and consider potential CNSsparing regimens (Forgacs et al. 2005, Maramattom et al. 2004). High rates of emotional distress, acutely and longer-term, suggest the role of more routine and systematized pre-transplantation evaluation and further outcomes research examining currently used and new treatment approaches (Rush et al. 2004).

Studies of neuroprotection or cognitive rehabilitation are in a period of relative infancy. Given the high prevalence of global neuropsychiatric deficits, trials are needed to clarify risk factors (Ahles et al. 2003) and to elucidate the role of agents with probable ameliorative or preventative benefit (O'Shaughnessy et al. 2005, Thompson et al. 2001). Alternatively, regimens with relatively high margins for safety could be assessed for efficacy in relief of cognitive disorder after initial onset (Cimprich et al. 2003). Finally, additional research into the neuropsychiatric sequelae of long-term survivors of HSCT is needed, particularly within the growing numbers of patients receiving nonmyeloablative conditioning regimens.

\section{References}

Acute adverse reactions to prednisone in relation to dosage. Clin Pharmacol Ther 1972; 13 (5): 694-698.

Adams F, Fernandez F, Mavligit G. Interferon-induced organic mental disorders associated with unsuspected preexisting neurologic abnormalities. J Neurooncol 1988; 6 (4): 355-359.

Ahles TA, Saykin AJ, Noll WW, Furstenberg CT, Guerin S, Cole B, et al. The relationship of APOE genotype to neuropsychological performance in long-term cancer survivors treated with standard dose chemotherapy. Psychooncology 2003; 12 (6): 612-619.

Ahles TA, Tope DM, Furstenberg C, Hann D, Mills L. Psychologic and neuropsychologic impact of autologous bone marrow transplantation. J Clin Oncol 1996; 14 (5): 1457-1462.

American Psychiatric Association. Diagnostic and Statistical Manual of Mental Disorders. Fourth Edition. Text Revision. ed. Washington, DC: American Psychiatric Association; 2000.

Anderson-Hanley C, Sherman ML, Riggs R, Agocha VB, Compas BE. Neuropsychological effects of treatments for adults with cancer: a meta-analysis and review of the literature. J Int Neuropsychol Soc 2003; 9 (7): 967-982.

Andrykowski MA, Altmaier EM, Barnett RL, Burish TG, Gingrich R, Henslee-Downey PJ. Cognitive dysfunction in adult survivors of allogeneic marrow transplantation: relationship to dose of total body irradiation. Bone Marrow Transplant 1990; 6 (4): 269-276.

Andrykowski MA, Henslee PJ, Barnett RL. Longitudinal assessment of psychosocial functioning of adult survivors of allogeneic bone marrow transplantation. Bone Marrow Transplant 1989; 4 (5): 505-509.

Andrykowski MA, Schmitt FA, Gregg ME, Brady MJ, Lamb DG, Henslee-Downey PJ. Neuropsychologic impairment in adult bone marrow transplant candidates. Cancer 1992; 70 (9): 2288-2297.

Appelbaum FR. The current status of hematopoietic cell transplantation. Annu Rev Med 2003; 54: 491-512.

Armstrong CL, Gyato K, Awadalla AW, Lustig R, Tochner ZA. A critical review of the clinical effects of therapeutic irradiation damage to the brain: the roots of controversy. Neuropsychol Rev 2004; 14 (1): 65-86. 
Aviles A, Nambo MJ, Neri N, Murillo E, Castaneda C, Cleto $\mathrm{S}$, et al. Biological modifiers as cytoreductive therapy before stem cell transplant in previously untreated patients with multiple myeloma. Ann Oncol 2005; 16 (2): 219-221.

Ay H, Buonanno FS, Schaefer PW, Le DA, Wang B, Gonzalez RG, et al. Posterior leukoencephalopathy without severe hypertension: utility of diffusion-weighted MRI. Neurology 1998; 51 (5): 1369-1376.

Bartynski WS, Grabb BC, Zeigler Z, Lin L, Andrews DF. Watershed imaging features and clinical vascular injury in cyclosporin A neurotoxicity. J Comput Assist Tomogr 1997; 21 (6): 872-880.

Bartynski WS, Zeigler Z, Spearman MP, Lin L, Shadduck RK, Lister J. Etiology of cortical and white matter lesions in cyclosporin-A and FK-506 neurotoxicity. AJNR Am J Neuroradiol 2001; 22 (10): 1901-1914.

Bartynski WS, Zeigler ZR, Shadduck RK, Lister J. Pretransplantation conditioning influence on the occurrence of cyclosporine or FK-506 neurotoxicity in allogeneic bone marrow transplantation. AJNR Am J Neuroradiol 2004; 25 (2): 261-269.

Belka C, Budach W, Kortmann RD, Bamberg M. Radiation induced CNS toxicity--molecular and cellular mechanisms. Br J Cancer 2001; 85 (9): 1233-1239.

Blay JY, Conroy T, Chevreau C, Thyss A, Quesnel N, Eghbali H, et al. High-dose methotrexate for the treatment of primary cerebral lymphomas: analysis of survival and late neurologic toxicity in a retrospective series. J Clin Oncol 1998; 16 (3): 864-871.

Bleistein J, Braunig P. [EEG findings in cortisone psychoses-a retrospective study in 10 patients]. EEG EMG Z Elektroenzephalogr Elektromyogr Verwandte Geb 1989; 20 (2): 112-116.

Blesch KS, Paice JA, Wickham R, Harte N, Schnoor DK, Purl S, et al. Correlates of fatigue in people with breast or lung cancer. Oncol Nurs Forum 1991; 18 (1): 8187.

Boogaerts MA, Zachee P, Verwilghen RL. Cyclosporin, methylprednisolone, and convulsions. Lancet 1982; 2 (8309): 1216-1217.

Bower JE, Ganz PA, Aziz N. Altered cortisol response to psychologic stress in breast cancer survivors with persistent fatigue. Psychosom Med 2005; 67 (2): 277-280.

Bower JE, Ganz PA, Aziz N, Fahey JL. Fatigue and proinflammatory cytokine activity in breast cancer survivors. Psychosom Med 2002; 64 (4): 604-611.

Bower JE, Ganz PA, Aziz N, Fahey JL, Cole SW. T-cell homeostasis in breast cancer survivors with persistent fatigue. J Natl Cancer Inst 2003; 95 (15): 1165-1168.
Breitbart W, Gibson C, Tremblay A. The delirium experience: delirium recall and delirium-related distress in hospitalized patients with cancer, their spouses/caregivers, and their nurses. Psychosomatics 2002; 43 (3): 183-194.

Brown T, Stoudemire A. Psychiatric side-effects of prescription and over-the-counter medications recognition and management. Washington, DC: American Psychiatric Press; 1998. p. 244.

Buckanovich RJ, Liu G, Stricker C, Luger SM, Stadtmauer EA, Schuster SJ, Duffy K, et al. Nonmyeloablative allogeneic stem cell transplantation for refractory Hodgkin's lymphoma complicated by interleukin-2 responsive progressive multifocal leukoencephalopathy. Ann Hematol 2002; 81 (7): 410-413.

Bush NE, Donaldson GW, Haberman MH, Dacanay R, Sullivan KM. Conditional and unconditional estimation of multidimensional quality of life after hematopoietic stem cell transplantation: a longitudinal follow-up of 415 patients. Biol Blood Marrow Transplant 2000; 6 (5A): 576591.

Callewaert DM, Moudgil VK, Radcliff G, Waite R. Hormone specific regulation of natural killer cells by cortisol. Direct inactivation of the cytotoxic function of cloned human NK cells without an effect on cellular proliferation. FEBS Lett 1991; 285 (1): 108-110.

Cammer W. Effects of TNFalpha on immature and mature oligodendrocytes and their progenitors in vitro. Brain Res 2000; 864 (2): 213-219.

Capuron L, Gumnick JF, Musselman DL, Lawson DH, Reemsnyder A, Nemeroff CB, et al. Neurobehavioral effects of interferon-alpha in cancer patients: phenomenology and paroxetine responsiveness of symptom dimensions. Neuropsychopharmacology 2002; 26 (5): 643-652.

Caraceni A, Nanni O, Maltoni M, Piva L, Indelli M, Arnoldi E, et al. Impact of delirium on the short term prognosis of advanced cancer patients. Italian Multicenter Study Group on Palliative Care. Cancer 2000; 89 (5): 1145-1149.

Carpiniello B, Orru MG, Baita A, Pariante CM, Farci G. Mania induced by withdrawal of treatment with interferon alfa. Arch Gen Psychiatry 1998; 55 (1): 88-89.

Cersosimo RJ. Cisplatin neurotoxicity. Cancer Treat Rev 1989; 16 (4): 195-211.

Chang G, Orav EJ, McNamara T, Tong MY, Antin JH. Depression, cigarette smoking, and hematopoietic stem cell transplantation outcome. Cancer 2004; 101 (4): 782789.

Chang G, Orav EJ, McNamara TK, Tong MY, Antin JH. Psychosocial function after hematopoietic stem cell transplantation. Psychosomatics 2005; 46 (1): 34-40. 
Cheson BD, Vena DA, Foss FM, Sorensen JM. Neurotoxicity of purine analogs: a review. J Clin Oncol 1994; 12(10): 2216-2228.

Chohan R, Vij R, Adkins D, Blum W, Brown R, Tomasson $\mathrm{M}$, et al. Long-term outcomes of allogeneic stem cell transplant recipients after calcineurin inhibitor-induced neurotoxicity. Br J Haematol 2003; 123 (1): 110-113.

Chun HG, Leyland-Jones BR, Caryk SM, Hoth DF. Central nervous system toxicity of fludarabine phosphate. Cancer Treat Rep 1986; 70(10): 1225-1228.

Cimprich B, Ronis DL. An environmental intervention to restore attention in women with newly diagnosed breast cancer. Cancer Nurs 2003; 26 (4): 284-292.

Classen CF, Schulz AS, Debatin KM, Friedrich W. Severe persistent neuropsychiatric toxicity after a human leucocyte antigen-non-identical peripheral blood stem cell transplantation (total body irradiation, etoposide, thiotepa) and interleukin 2-based experimental therapy for poor prognosis relapse acute lymphoblastic leukaemia. $\mathrm{Br} \mathrm{J}$ Haematol 2001; 114 (2): 487-489.

Cooper DK, Novitzky D, Davis L, Huff JE, Parker D, Schlesinger R, et al. Does central nervous system toxicity occur in transplant patients with hypocholesterolemia receiving cyclosporine? J Heart Transplant 1989; 8 (3): 221-224.

Covarrubias DJ, Luetmer PH, Campeau NG. Posterior reversible encephalopathy syndrome: prognostic utility of quantitative diffusion-weighted MR images. AJNR Am J Neuroradiol 2002; 23 (6): 1038-1048.

Craven JL. Cyclosporine-associated organic mental disorders in liver transplant recipients. Psychosomatics 1991; 32 (1): 94-102.

Curt GA, Breitbart W, Cella D, Groopman JE, Horning SJ, et al. Impact of cancer-related fatigue on the lives of patients: new findings from the Fatigue Coalition. Oncologist 2000; 5 (5): 353-360.

Dantzer R. Somatization: a psychoneuroimmune perspective. Psychoneuroendocrinology 2005; 30 (10): 947952.

Davis S, Mirick DK, Stevens RG. Night shift work, light at night, and risk of breast cancer. J Natl Cancer Inst 2001; 93 (20): 1557-1562.

DiMaggio JR, Brown R, Baile WF, Schapira D. Hallucinations and ifosfamide-induced neurotoxicity. Cancer 1994; 73 (5): 1509-1514.

Doll DC, List AF, Greco FA, Hainsworth JD, Hande $\mathrm{KR}$, et al. Acute vascular ischemic events after cisplatinbased combination chemotherapy for germ-cell tumors of the testis. Ann Intern Med 1986; 105 (1): 48-51.
Edelman RR, Warach S. Magnetic resonance imaging (1). N Engl J Med 1993; 328 (10): 708-716.

Edwards LL, Wszolek ZK, Normand MM. Neurophysiologic evaluation of cyclosporine toxicity associated with bone marrow transplantation. Acta Neurol Scand 1996; 94 (5): 358-364.

Eissner G, Kohlhuber F, Grell M, Ueffing M, Scheurich $\mathrm{P}$, Hieke A, et al. Critical involvement of transmembrane tumor necrosis factor-alpha in endothelial programmed cell death mediated by ionizing radiation and bacterial endotoxin. Blood 1995; 86 (11): 4184-4193.

El-Banna MM, Berger AM, Farr L, Foxall MJ, Friesth $\mathrm{B}$, et al. Fatigue and depression in patients with lymphoma undergoing autologous peripheral blood stem cell transplantation. Oncol Nurs Forum 2004; 31 (5): 937-944.

Fann JR, Alfano CM, Burington BE, Roth-Roemer S, Katon WJ, Syrjala KL. Clinical presentation of delirium in patients undergoing hematopoietic stem cell transplantation. Cancer 2005; 103 (4): 810-820.

Fann JR, Roth-Roemer S, Burington BE, Katon WJ, Syrjala KL. Delirium in patients undergoing hematopoietic stem cell transplantation. Cancer 2002; 95 (9): 1971-1981.

Fann JR, Sullivan AK. Delirium in the course of cancer treatment. Semin Clin Neuropsychiatry 2003; 8 (4): 217 228.

Farkkila M, Iivanainen M, Roine R, Bergstrom L, Laaksonen R, et al. Neurotoxic and other side effects of highdose interferon in amyotrophic lateral sclerosis. Acta Neurol Scand 1984; 70 (1): 42-46.

Filipski E, King VM, Li X, Granda TG, Mormont MC, Liu X, et al. Host circadian clock as a control point in tumor progression. J Natl Cancer Inst 2002; 94 (9): 690697.

Forgacs B, Merhav HJ, Lappin J, Mieles L. Successful conversion to rapamycin for calcineurin inhibitor-related neurotoxicity following liver transplantation. Transplant Proc 2005; 37 (4): 1912-1914.

Friedman JH, Shetty N. Permanent cerebellar toxicity of cytosine arabinoside (Ara C) in a young woman. Mov Disord 2001; 16 (3): 575-577.

Geinstein L, Sandmaier B. Nonmyeloblative transplantation. In: RJ Soiffer, translator and editor. Stem Cell Transplanation of Hemotologic Malignancies. Totowa, NJ: Humana Press; 2004; p. 469-482.

Goldberg SL, Pecora AL, Alter RS, Kroll MS, Rowley $\mathrm{SD}$, Waintraub SE, et al. Unusual viral infections (progressive multifocal leukoencephalopathy and cytomegalovirus disease) after high-dose chemotherapy with autologous blood stem cell rescue and peritransplantation rituximab. Blood 2002; 99 (4): 1486-1488. 
Goldberg SL, Tefferi A, Rummans TA, Chen MG, Solberg LA, Noel P. Post-irradiation somnolence syndrome in an adult patient following allogeneic bone marrow transplantation. Bone Marrow Transplant 1992; 9 (6): 499-501.

Goldman JM, Horowitz MM. The international bone marrow transplant registry. Int J Hematol 2002; 76 Suppl 1: S393-S397.

Gonzalez H, Bolgert F, Camporo P, Leblond V. Progressive multifocal leukoencephalitis (PML) in three patients treated with standard-dose fludarabine (FAMP). Hematol Cell Ther 1999; 41(4): 183-186.

Grassi L, Rosti G, Albertazzi L, Marangolo M. Depressive symptoms in autologous bone marrow transplant (ABMT) patients with cancer: An exploratory study. Psycho-Oncology 1996; 5 (4): 305-310.

Hackanson B, Zeiser R, Bley TA, Pantazis G, Huzly D, Bertz H, Finke J. Fatal varicella zoster virus encephalitis in two patients following allogeneic hematopoietic stem cell transplantation. Clin Transplant 2005; 19 (4): 566-570.

Hammond IW, Ferguson JA, Kwong K, Muniz E, Delisle F. Hyponatremia and syndrome of inappropriate anti-diuretic hormone reported with the use of Vincristine: an over-representation of Asians? Pharmacoepidemiol Drug Saf 2002; 11 (3): 229-234.

Han L, McCusker J, Cole M, Abrahamowicz M, Primeau F, Elie M. Use of medications with anticholinergic effect predicts clinical severity of delirium symptoms in older medical inpatients. Arch Intern Med 2001; 161 (8): 1099-1105.

Hanisch UK, Neuhaus J, Quirion R, Kettenmann H. Neurotoxicity induced by interleukin-2: involvement of infiltrating immune cells. Synapse 1996; 24 (2): 104-114.

Hann DM, Garovoy N, Finkelstein B, Jacobsen PB, Azzarello LM, Fields KK. Fatigue and quality of life in breast cancer patients undergoing autologous stem cell transplantation: a longitudinal comparative study. J Pain Symptom Manage 1999; 17 (5): 311-319.

Hansen SW. Autonomic neuropathy after treatment with cisplatin, vinblastine, and bleomycin for germ cell cancer. BMJ 1990; 300 (6723): 511-512.

Hansen SW, Helweg-Larsen S, Trojaborg W. Long-term neurotoxicity in patients treated with cisplatin, vinblastine, and bleomycin for metastatic germ cell cancer. J Clin Oncol 1989; 7 (10): 1457-1461.

Harder H, Van Gool AR, Cornelissen JJ, Duivenvoorden HJ, Eijkenboom WM, et al. Assessment of pre-treatment cognitive performance in adult bone marrow or haematopoietic stem cell transplantation patients: a comparative study. Eur J Cancer 2005; 41 (7): 1007-1016.
Heinonen H, Volin L, Uutela A, Zevon M, Barrick C, Ruutu T. Gender-associated differences in the quality of life after allogeneic BMT. Bone Marrow Transplant 2001; 28 (5): 503-509.

Hensel M, Egerer G, Schneeweiss A, Goldschmidt H, Ho AD. Quality of life and rehabilitation in social and professional life after autologous stem cell transplantation. Ann Oncol 2002; 13 (2): 209-217.

Hentrich M, Oruzio D, Jager G, Schlemmer M, Schleuning $\mathrm{M}$, et al. Impact of human herpesvirus- 6 after haematopoietic stem cell transplantation. Br J Haematol 2005; 128 (1): 66-72.

Hinchey J, Chaves C, Appignani B, Breen J, Pao L, Wang A, et al. A reversible posterior leukoencephalopathy syndrome. N Engl J Med 1996; 334 (8): 494-500.

Hjermstad MJ, Knobel H, Brinch L, Fayers PM, Loge $\mathrm{JH}$, Holte $\mathrm{H}$, et al. A prospective study of health-related quality of life, fatigue, anxiety and depression 3-5 years after stem cell transplantation. Bone Marrow Transplant 2004; 34 (3): 257-266.

Hjermstad MJ, Loge JH, Evensen SA, Kvaloy SO, Fayers PM, Kaasa S. The course of anxiety and depression during the first year after allogeneic or autologous stem cell transplantation. Bone Marrow Transplant 1999; 24 (11): 1219-1228.

Holler E, Kolb HJ, Hiller E, Mraz W, Lehmacher W, Gleixner B, et al. Microangiopathy in patients on cyclosporine prophylaxis who developed acute graft-versus-host disease after HLA-identical bone marrow transplantation. Blood 1989; 73 (7): 2018-2024.

Hussain M, Wozniak AJ, Edelstein MB. Neurotoxicity of antineoplastic agents. Crit Rev Oncol Hematol 1993; 14 (1): 61-75.

Iivanainen M, Laaksonen R, Niemi ML, Farkkila M, Bergstrom L, Mattson K, et al. Memory and psychomotor impairment following high-dose interferon treatment in amyotrophic lateral sclerosis. Acta Neurol Scand 1985; 72 (5): 475-480.

Imrie KR, Couture F, Turner CC, Sutcliffe SB, Keating A. Peripheral neuropathy following high-dose etoposide and autologous bone marrow transplantation. Bone Marrow Transplant 1994; 13 (1): 77-79.

Inbar M, Merimsky O, Wigler N, Chaitchik S. Cisplatin-related Lhermitte's sign. Anticancer Drugs 1992; 3 (4): 375-377.

Ito Y, Arahata Y, Goto Y. Cisplatin neurotoxicity presenting as reversible posterior leukoencephalopathy syndrome. AJNR Am J Neuroradiol 1998; 19: 41-45.

Jacobson S, Jerrier H. EEG in delirium. Semin Clin Neuropsychiatry 2000; 5 (2): 86-92. 
Julin JE, van Burik JH, Krivit W, Webb C, Holman CJ, Clark HB, et al. Ganciclovir-resistant cytomegalovirus encephalitis in a bone marrow transplant recipient. Transpl Infect Dis 2002; 4 (4): 201-206.

Kaczmarek I, Groetzner J, Meiser B, Mueller M, Landwehr P, Ueberfuhr P, et al. Impairment of the bloodbrain barrier can result in tacrolimus-induced reversible leucoencephalopathy following heart transplantation. Clin Transplant 2003; 17 (5): 469-472.

Karp BI, Yang JC, Khorsand M, Wood R, Merigan TC. Multiple cerebral lesions complicating therapy with interleukin-2. Neurology 1996; 47 (2): 417-424.

Keenan PA, Jacobson MW, Soleymani RM, Mayes MD, Stress ME, Yaldoo DT. The effect on memory of chronic prednisone treatment in patients with systemic disease. Neurology 1996; 47 (6): 1396-1402.

Kende G, Sirkin SR, Thomas PR, Freeman AI. Blurring of vision: a previously undescribed complication of cyclophosphamide therapy. Cancer 1979; 44 (1): 69-71.

Kiecolt-Glaser JK, Stephens RE, Lipetz PD, Speicher CE, Glaser R. Distress and DNA repair in human lymphocytes. J Behav Med 1985; 8 (4): 311-320.

Klastersky J. Side effects of ifosfamide. Oncology 2003; 65 Suppl 2: S7-S10.

Knobel H, Loge JH, Nordoy T, Kolstad AL, Espevik T, Kvaloy S, et al. High level of fatigue in lymphoma patients treated with high dose therapy. J Pain Symptom Manage 2000; 19 (6): S446-S456.

La Morgia C, Mondini S, Guarino M, Bonifazi F, Cirignotta F. Busulfan neurotoxicity and EEG abnormalities: a case report. Neurol Sci 2004; 25 (2): 95-97.

Lai R, Abrey LE, Rosenblum MK, DeAngelis LM. Treatment-induced leukoencephalopathy in primary CNS lymphoma: a clinical and autopsy study. Neurology 2004; 62 (3): 451-456.

Lee SJ, Loberiza FR, Antin JH, Kirkpatrick T, Prokop $\mathrm{L}$, et al. Routine screening for psychosocial distress following hematopoietic stem cell transplantation. Bone Marrow Transplant 2005; 35 (1): 77-83.

Leff RS, Thompson JM, Daly MB, Johnson DB, Harden EA, Mercier RJ, et al. Acute neurologic dysfunction after high-dose etoposide therapy for malignant glioma. Cancer 1988; 62 (1): 32-35.

Leniger T, Kastrup O, Diener HC. Reversible posterior leukencephalopathy syndrome induced by granulocyte stimulating factor filgrastim.J Neurol Neurosurg Psychiatry. 2000 Aug; 69(2): 280-281.

Lerner DM, Stoudemire A, Rosenstein DL. Neuropsychiatric toxicity associated with cytokine therapies. Psychosomatics 1999; 40 (5): 428-435.
Levav I, Kohn R, Iscovich J, Abramson JH, Tsai WY, Vigdorovich D. Cancer incidence and survival following bereavement. Am J Public Health 2000; 90 (10): 16011607.

Levy S, Herberman R, Lippman M, d'Angelo T. Correlation of stress factors with sustained depression of natural killer cell activity and predicted prognosis in patients with breast cancer. J Clin Oncol 1987; 5 (3): 348-353.

Lewis A, Fleminger JJ. The psychiatric risk from corticotrophin and cortisone. Lancet 1954; 266 (6808): 383386.

Lewis DA, Smith RE. Steroid-induced psychiatric syndromes. A report of 14 cases and a review of the literature. $J$ Affect Disord 1983; 5 (4): 319-332.

Lien HH, Blomlie V, Saeter G, Solheim O, Fossa SD. Osteogenic sarcoma: MR signal abnormalities of the brain in asymptomatic patients treated with high-dose methotrexate. Radiology 1991; 179 (2): 547-550.

Ljubisavljevic V, Kelly B. Risk factors for development of delirium among oncology patients. Gen Hosp Psychiatry 2003; 25 (5): 345-352.

Loberiza FR, Jr., Rizzo JD, Bredeson CN, Antin JH, Horowitz MM, Weeks JC, et al. Association of depressive syndrome and early deaths among patients after stem-cell transplantation for malignant diseases. J Clin Oncol 2002; 20 (8): 2118-2126.

Lyass O, Lossos A, Hubert A, Gips M, Peretz T. Cisplatin-induced non-convulsive encephalopathy. Anticancer Drugs 1998; 9 (1): 100-104.

Mahaley MS, Jr., Whaley RA, Blue M, Bertsch L. Central neurotoxicity following intracarotid BCNU chemotherapy for malignant gliomas. J Neurooncol 1986; 3 (4): 297-314

Maramattom BV, Wijdicks EF. Sirolimus may not cause neurotoxicity in kidney and liver transplant recipients. Neurology 2004; 63 (10): 1958-1959.

Mark AL. Cyclosporine, sympathetic activity, and hypertension. N Engl J Med 1990; 323 (11): 748-750.

Massie MJ,Popkin MK. Depressive disorders. In: Holland JC, (Ed) Psycho-oncology. New York: Oxford University Press, 1998: 518-540.

Matteucci P, Magni M, Di Nicola M, Carlo-Stella C, Uberti C, Gianni AM. Leukoencephalopathy and papovavirus infection after treatment with chemotherapy and anti-CD20 monoclonal antibody. Blood 2002; 100 (3): 1104-1105.

Mattson K, Niiranen A, Iivanainen M, Farkkila M, Bergstrom L, Holsti LR, Kauppinen HL, et al. Neurotoxicity of interferon. Cancer Treat Rep 1983; 67 (10): 958-961. 
McQuellon RP, Russell GB, Rambo TD, Craven BL, Radford J, Perry JJ, et al. Quality of life and psychological distress of bone marrow transplant recipients: the 'time trajectory' to recovery over the first year. Bone Marrow Transplant 1998; 21(5): 477-486.

Menkes DB, MacDonald JA. Interferons, serotonin and neurotoxicity. Psychol Med 2000 Mar; 30 (2): 259-68.

Metitieri T, Bianchetti A, Trabucchi M. Delirium as a predictor of survival in older patients with advanced cancer. Arch Intern Med 2000; 160 (18): 2866-2868.

Meyers CA, Scheibel RS, Forman AD. Persistent neurotoxicity of systemically administered interferon-alpha. Neurology 1991; 41 (5): 672-676.

Meyers CA, Weitzner M, Byrne K, Valentine A, Champlin RE, Przepiorka D. Evaluation of the neurobehavioral functioning of patients before, during, and after bone marrow transplantation. J Clin Oncol 1994; 12 (4): 820-826.

Misawa A, Takeuchi Y, Hibi S, Todo S, Imashuku S, Sawada T. FK506-induced intractable leukoencephalopathy following allogeneic bone marrow transplantation. Bone Marrow Transplant 2000; 25 (3): 331-334.

Monga U, Kerrigan AJ, Thornby J, Monga TN. Prospective study of fatigue in localized prostate cancer patients undergoing radiotherapy. Radiat Oncol Investig 1999; 7 (3): 178-185.

Monji A, Yoshida I, Tashiro K, Hayashi Y, Tashiro N. A case of persistent manic depressive illness induced by interferon-alfa in the treatment of chronic hepatitis C. Psychosomatics 1998; 39 (6): 562-564.

Moore BE, Somers NP, Smith TW. Methotrexate-related nonnecrotizing multifocal axonopathy detected by betaamyloid precursor protein immunohistochemistry. Arch Pathol Lab Med 2002; 126 (1): 79-81.

Morita T, Tsunoda J, Inoue S, Chihara S. Survival prediction of terminally ill cancer patients by clinical symptoms: development of a simple indicator. Jpn J Clin Oncol 1999; 29 (3): 156-159.

Moynihan JA. Mechanisms of stress-induced modulation of immunity. Brain Behav Immun 2003; 17 Suppl 1: S11-S16.

Mukherjee P, McKinstry RC. Reversible posterior leukoencephalopathy syndrome: evaluation with diffusiontensor MR imaging. Radiology 2001; 219 (3): 756-765.

Musselman DL, Lawson DH, Gumnick JF, Manatunga AK, Penna S, et al. Paroxetine for the prevention of depression induced by high-dose interferon alfa. $N$ Engl J Med 2001; 344 (13): 961-966.

Muta T, Kamo M, Gondo H, Kato K, Eto T, Shibuya T, et al. Human herpesvirus- 6 encephalitis followed by severe acute GVHD after a stem cell transplant from a microchimeric non-inherited maternal antigen (NIMA)mismatched sibling. Bone Marrow Transplant 2005; 35 (4): 411-413.

Naber D, Sand P, Heigl B. Psychopathological and neuropsychological effects of 8-days' corticosteroid treatment. A prospective study. Psychoneuroendocrinology 1996; 21 (1): 25-31.

Neitzert CS, Ritvo P, Dancey J, Weiser K, Murray C, Avery J. The psychosocial impact of bone marrow transplantation: a review of the literature. Bone Marrow Transplant 1998; 22 (5): 409-422.

Neuhaus P, McMaster P, Calne R, Pichlmayr R, Otto G, Williams R, et al. Neurological complications in the European multicentre study of FK 506 and cyclosporin in primary liver transplantation. Transpl Int 1994; 7 Suppl 1: S27-S31.

Newcomer JW, Craft S, Hershey T, Askins K, Bardgett ME. Glucocorticoid-induced impairment in declarative memory performance in adult humans. J Neurosci 1994; 14 (4): 2047-2053.

Niiranen A, Laaksonen R, Iivanainen M, Mattson K, Farkkila M, Cantell K. Behavioral assessment of patients treated with alpha-interferon. Acta Psychiatr Scand 1988; 78 (5): 622-626.

Olofsson SM, Weitzner MA, Valentine AD, Baile WF, Meyers CA. A retrospective study of the psychiatric management and outcome of delirium in the cancer patient. Support Care Cancer 1996; 4 (5): 351-357.

Osborne WL, Holyoake TL, McQuaker IG, Parker AN. Fatal peripheral neuropathy following FLA chemotherapy. Clin Lab Haematol 2004; 26 (4): 295-296.

O'Shaughnessy JA, Vukelja SJ, Holmes FA, Savin M, Jones M, Royall D, et al. Feasibility of quantifying the effects of epoetin alfa therapy on cognitive function in women with breast cancer undergoing adjuvant or neoadjuvant chemotherapy. Clin Breast Cancer 2005; 5 (6): 439446.

Osorio S, de la Camara R, Golbano N, Marti E, Fedele $\mathrm{CG}$, Nieto $\mathrm{S}$, et al. Progressive multifocal leukoencephalopathy after stem cell transplantation, unsuccessfully treated with cidofovir. Bone Marrow Transplant 2002; 30 (12): 963-966.

Otsuka F, Hayashi Y, Ogura T, Hayakawa N, Ikeda S, Makino H, et al. Syndrome of inappropriate secretion of antidiuretic hormone following intra-thoracic cisplatin. Intern Med 1996; 35 (4): 290-294.

Owens MJ, Nemeroff CB. The role of corticotropinreleasing factor in the pathophysiology of affective and anxiety disorders: laboratory and clinical studies. Ciba Found Symp 1993; 172: 296-308. 
Padgett BL, Walker DL. Virologic and serologic studies of progressive multifocal leukoencephalopathy. Prog Clin Biol Res 1983; 105: 107-117.

Pettitt AR, Clark RE. Thrombotic microangiopathy following bone marrow transplantation. Bone Marrow Transplant 1994; 14 (4): 495-504.

Pho MT, Ashok A, Atwood WJ. JC virus enters human glial cells by clathrin-dependent receptor-mediated endocytosis. J Virol 2000; 74 (5): 2288-2292.

Pirl WF, Roth AJ. Diagnosis and treatment of depression in cancer patients. Oncology (Williston Park) 1999; 13 (9): 1293-1301.

Poutiainen E, Hokkanen L, Niemi ML, Farkkila M. Reversible cognitive decline during high-dose alpha-interferon treatment. Pharmacol Biochem Behav 1994; 47 (4): 901-905.

Prieto JM, Atala J, Blanch J, Carreras E, Rovira M, Cirera E, et al. Role of depression as a predictor of mortality among cancer patients after stem-cell transplantation. $J$ Clin Oncol 2005a; 23 (25): 6063-6071.

Prieto JM, Atala J, Blanch J, Carreras E, Rovira M, Cirera E, et al. Patient-rated emotional and physical functioning among hematologic cancer patients during hospitalization for stem-cell transplantation. Bone Marrow Transplant 2005b; 35 (3): 307-314.

Prieto JM, Blanch J, Atala J, Carreras E, Rovira M, Cirera E, et al. Psychiatric morbidity and impact on hospital length of stay among hematologic cancer patients receiving stem-cell transplantation. J Clin Oncol 2002; 20 (7): 1907-1917.

Provenzale JM, Petrella JR, Cruz LC, Jr., Wong JC, Engelter S, Barboriak DP. Quantitative assessment of diffusion abnormalities in posterior reversible encephalopathy syndrome. AJNR Am J Neuroradiol 2001; 22 (8): 1455-1461.

Raison CL, Demetrashvili M, Capuron L, Miller AH. Neuropsychiatric adverse effects of interferon-alpha: recognition and management. CNS Drugs 2005; 19 (2): 105-123.

Reiche EM, Nunes SO, Morimoto HK. Stress, depression, the immune system, and cancer. Lancet Oncol 2004; 5 (10): 617-625.

Reischies FM, Neuhaus AH, Hansen ML, Mientus S, Mulert C, Gallinat J. Electrophysiological and neuropsychological analysis of a delirious state: the role of the anterior cingulate gyrus. Psychiatry Res 2005; 138 (2): 171181.

Rieger C, Fiegl M, Tischer J, Ostermann H, Schiel X. Incidence and severity of ifosfamide-induced encephalopathy. Anticancer Drugs 2004; 15 (4): 347-350.
Rohatiner AZ, Prior PF, Burton AC, Smith AT, Balkwill FR, Lister TA. Central nervous system toxicity of interferon. Br J Cancer 1983; 47 (3): 419-422.

Rome HP, Braceland FJ. Use of cortisone and ACTH in certain diseases: psychiatric aspects. Mayo Clin Proc 1950; 25 (17): 495-497.

Rowse GJ, Weinberg J, Bellward GD, Emerman JT. Endocrine mediation of psychosocial stressor effects on mouse mammary tumor growth. Cancer Lett 1992; 65 (1): 85-93.

Rubinstein LJ, Herman MM, Long TF, Wilbur JR. Disseminated necrotizing leukoencephalopathy: a complication of treated central nervous system leukemia and lymphoma. Cancer 1975; 35 (2): 291-305.

Rubnitz JE, Relling MV, Harrison PL, Sandlund JT, Ribeiro RC, Rivera GK, et al. Transient encephalopathy following high-dose methotrexate treatment in childhood acute lymphoblastic leukemia. Leukemia 1998; 12 (8): 1176-1181.

Rush AJ, Fava M, Wisniewski SR, Lavori PW, Trivedi $\mathrm{MH}$, Sackeim HA, et al. Sequenced treatment alternatives to relieve depression $\left(\mathrm{STAR}^{*} \mathrm{D}\right)$ : rationale and design. Control Clin Trials 2004; 25 (1): 119-142.

Rzeski W, Pruskil S, Macke A, Felderhoff-Mueser U, Reiher AK, Hoerster F, et al. Anticancer agents are potent neurotoxins in vitro and in vivo. Ann Neurol 2004;56(3): 351-360.

Schaefer M, Schwaiger M, Pich M, Lieb K, Heinz A. Neurotransmitter changes by interferon-alpha and therapeutic implications. Pharmacopsychiatry 2003; 36 Suppl 3: S203-S206.

Scherrer U, Vissing SF, Morgan BJ, Rollins JA, Tindall RS, Ring S, Hanson P, Mohanty PK, Victor RG. Cyclosporine-induced sympathetic activation and hypertension after heart transplantation. N Engl J Med 1990; 323 (11): 693-699.

Scudeletti M, Musselli C, Lanza L, Peirano L, Puppo F, Indiveri F. [The immunological activity of corticosteroids]. Recenti Prog Med 1996; 87 (10): 508-515.

Sergent JS, Lockshin MD, Klempner MS, Lipsky BA. Central nervous system disease in systemic lupus erythematosus. Therapy and prognosis. Am J Med 1975; 58 (5): 644-654.

Shitrit D, Lev N, Bar-Gil-Shitrit A, Kramer MR. Progressive multifocal leukoencephalopathy in transplant recipients. Transpl Int 2005; 17 (11): 658-665.

Siegal T, Haim N. Cisplatin-induced peripheral neuropathy. Frequent off-therapy deterioration, demyelinating syndromes, and muscle cramps. Cancer 1990; 66: 11-17. 
Sirois F. Steroid psychosis: a review. Gen Hosp Psychiatry $2003 ; 25$ (1): 27-33.

Smedley H, Katrak M, Sikora K, Wheeler T. Neurological effects of recombinant human interferon. Br Med J (Clin Res Ed) 1983; 286 (6361): 262-264.

Spiegel D, Giese-Davis J. Depression and cancer: mechanisms and disease progression. Biol Psychiatry 2003; 54 (3): 269-282.

Steurer M, Clausen J, Gotwald T, Gunsilius E, Stockhammer G, Gastl G, Nachbaur D. Progressive multifocal leukoencephalopathy after allogeneic stem cell transplantation and posttransplantation rituximab. Transplantation 2003; 76 (2): 435-436.

Stoudemire A, Anfinson T, Edwards J. Corticosteroidinduced delirium and dependency. Gen Hosp Psychiatry 1996; 18 (3): 196-202.

Strite D, Valentine AD, Meyers CA. Manic episodes in two patients treated with interferon alpha. J Neuropsychiatry Clin Neurosci 1997; 9 (2): 273-276.

Strouse TB, el-Saden SM, Glaser NE, Bonds C, Ayars $\mathrm{N}$, Busuttil RW. Immunosuppressant neurotoxicity in liver transplant recipients. Clinical challenges for the consultation-liaison psychiatrist. Psychosomatics 1998; 39 (2): 124-133.

Syrjala KL, Chapko MK, Vitaliano PP, Cummings C, Sullivan KM. Recovery after allogeneic marrow transplantation: prospective study of predictors of long-term physical and psychosocial functioning. Bone Marrow Transplant. 1993; 11(4): 319-327.

Syrjala KL, Dikmen S, Langer SL, Roth-Roemer S, Abrams JR. Neuropsychologic changes from before transplantation to 1 year in patients receiving myeloablative allogeneic hematopoietic cell transplant. Blood 2004a; 104 (10): 3386-3392.

Syrjala KL, Langer SL, Abrams JR, Storer B, Sanders JE, Flowers ME, Martin PJ. Recovery and long-term function after hematopoietic cell transplantation for leukemia or lymphoma. JAMA 2004b; 291 (19): 2335-2343.

Tada E, Yang C, Gobbel GT, Lamborn KR, Fike JR. Long-term impairment of subependymal repopulation following damage by ionizing irradiation. Exp Neurol 1999; 160 (1): 66-77.

Taylor MW, Feng GS. Relationship between interferongamma, indoleamine 2,3-dioxygenase, and tryptophan catabolism. FASEB J 199; 5 (11): 516-522.

Taylor MA, Vaidya NA. Psychopathology in neuropsychiatry: DSM and beyond. J Neuropsychiatry Clin Neurosci 2005; 17 (2): 246-249.

Thompson SJ, Leigh L, Christensen R, Xiong X, Kun LE, Heideman RL, Reddick WE, Gajjar A, Merchant T,
Pui CH, Hudson MM, Mulhern RK. Immediate neurocognitive effects of methylphenidate on learning-impaired survivors of childhood cancer. J Clin Oncol 2001; 19 (6): 1802-1808.

Tomei LD, Kiecolt-Glaser JK, Kennedy S, Glaser R. Psychological stress and phorbol ester inhibition of radiation-induced apoptosis in human peripheral blood leukocytes. Psychiatry Res 1990; 33 (1): 59-71.

Troy L, McFarland K, Littman-Power S, Kelly BJ, Walpole ET, Wyld D, Thomson D. Cisplatin-based therapy: a neurological and neuropsychological review. Psychooncology 2000; 9 (1): 29-39.

Trullemans F, Grignard F, Van Camp B, Schots R. Clinical findings and magnetic resonance imaging in severe cyclosporine-related neurotoxicity after allogeneic bone marrow transplantation. Eur J Haematol 2001; 67 (2): 9499.

Tsujimura H, Iseki T, Date Y, Watanabe J, Kumagai K, Kikuno K, Yonemitsu H, Saisho H. Human herpesvirus-6 encephalitis after bone marrow transplantation: magnetic resonance imaging could identify the involved sites of encephalitis. Eur J Haematol 1998; 61 (4): 284-285.

Tuxen MK, Hansen SW. Neurotoxicity secondary to antineoplastic drugs. Cancer Treat Rev 1994; 20 (2): 191214.

van der Maazen RW, Verhagen I, Kleiboer BJ, van der Kogel AJ. Radiosensitivity of glial progenitor cells of the perinatal and adult rat optic nerve studied by an in vitro clonogenic assay. Radiother Oncol 1991; 20 (4): 258-264.

van der Maazen RW, Verhagen I, van der Kogel AJ. An in vitro clonogenic assay to assess radiation damage in rat CNS glial progenitor cells. Int J Radiat Biol 1990; 58 (5): 835-844.

van Hemert AM, van der Mast RC, Hengeveld MW, Vorstenbosch M. Excess mortality in general hospital patients with delirium: a 5-year follow-up of 519 patients seen in psychiatric consultation. J Psychosom Res 1994; 38 (4): 339-346.

Varney NR, Alexander B, MacIndoe JH. Reversible steroid dementia in patients without steroid psychosis. Am J Psychiatry 1984; 141 (3): 369-372.

Verstappen C, Heimans J, Hoekman K, Postma T. Neurotoxic complications of chemotherapy in patients with cancer. Drugs 2003; 63: 1550.

Vezmar S, Becker A, Bode U, Jaehde U. Biochemical and clinical aspects of methotrexate neurotoxicity. Chemotherapy 2003; 49 (1-2): 92-104.

Vidarsson B, Mosher DF, Salamat MS, Isaksson HJ, Onundarson PT. Progressive multifocal leukoencephalopa- 
thy after fludarabine therapy for low-grade lymphoproliferative disease. Am J Hematol 2002 ; 70(1): 51-54.

Vogelzang NJ, Breitbart W, Cella D, Curt GA, Groopman JE, Horning SJ, Itri LM, Johnson DH, et al. Patient, caregiver, and oncologist perceptions of cancer-related fatigue: results of a tripart assessment survey. The Fatigue Coalition. Semin Hematol 1997; 34 (3 Suppl 2): S4-S12.

Vose JM, Kennedy BC, Bierman PJ, Kessinger A, Armitage JO. Long-term sequelae of autologous bone marrow or peripheral stem cell transplantation for lymphoid malignancies. Cancer 1992; 69 (3): 784-789.

Walker LG, Walker MB, Heys SD, Lolley J, Wesnes K, Eremin O. The psychological and psychiatric effects of rIL-2 therapy: a controlled clinical trial. Psychooncology 1997; 6 (4): 290-301.

Walker RW, Allen JC, Rosen G, Caparros B. Transient cerebral dysfunction secondary to high-dose methotrexate. J Clin Oncol 1986; 4 (12): 1845-1850.

Wang HY. Pathologic quiz case: a 54-year-old deceased man with diffuse subcortical lesions of the central nervous system. Progressive multifocal leukoencephalopathy. Arch Pathol Lab Med 2004; 128 (4): e70-72.

Warrell RP Jr, Berman E. Phase I and II study of fludarabine phosphate in leukemia: therapeutic efficacy with delayed central nervous system toxicity. J Clin Oncol 1986; 4(1): 74-79.

Wassenberg MW, Bromberg JE, Witkamp TD, Terhaard $\mathrm{CH}$, Taphoorn MJ. White matter lesions and encephalopathy in patients treated for primary central nervous system lymphoma. J Neurooncol 2001; 52 (1): 73-80.

Wenz F, Steinvorth S, Lohr F, Fruehauf S, Wildermuth $S$, van Kampen M, Wannenmacher M. Prospective evaluation of delayed central nervous system (CNS) toxicity of hyperfractionated total body irradiation (TBI). Int J Radiat Oncol Biol Phys 2000; 48 (5): 1497-1501.

Wettergren L, Langius A, Bjorkholm M, Bjorvell $\mathrm{H}$. Post-traumatic stress symptoms in patients undergoing autologous stem cell transplantation. Acta Oncol 1999; 38 (4): 475-480.

Wolkowitz OM, Reus VI, Weingartner H, Thompson K, Breier A, Doran A, Rubinow D, Pickar D. Cognitive effects of corticosteroids. Am J Psychiatry 1990; 147 (10): 1297 1303.

Yang W, Wang Q, Kanes SJ, Murray JM, Nishikura K. Altered RNA editing of serotonin 5-HT2C receptor induced by interferon: implications for depression associated with cytokine therapy. Brain Res Mol Brain Res 2004 Apr 29; 124 (1): 70-78.

Yehuda R, Teicher MH, Trestman RL, Levengood RA, Siever LJ. Cortisol regulation in posttraumatic stress disorder and major depression: a chronobiological analysis. Biol Psychiatry 1996; 40 (2): 79-88.

Zawacki T, Friedman JH, Grace J, Shetty N. Cerebellar toxicity of cytosine arabinoside: clinical and neuropsychological signs. Neurology 2000; 55 (8): 1234.

Zerr DM, Corey L, Kim HW, Huang ML, Nguy L, Boeckh M. Clinical outcomes of human herpesvirus 6 reactivation after hematopoietic stem cell transplantation. Clin Infect Dis 2005; 40 (7): 932-940.

Zimmer WE, Hourihane JM, Wang HZ, Schriber JR. The effect of human leukocyte antigen disparity on cyclosporine neurotoxicity after allogeneic bone marrow transplantation. Am J Neuroradiol 1998; 19 (4): 601-608; discussion 609-610.

Address of correspondence:

Mitch Levy, MD

Department of Psychiatry \& Behavioral Sciences

Box 354694

University of Washington School of Medicine

4225 Roosevelt Way NE, Suite 306

Seattle, WA 98105

PH: (206) 598-7792

FAX: (206) 598-7794

E-mail: mrlevy@u.washington.edu USA 